\title{
RESEARCHES OF THE INFLUENCE OF NITRATE CONTENTS ON MAIN MORPHOLOGICAL TRAITS OF MAIZE PLANTS
}

\author{
ADINA PETRUȚA JIPA ${ }^{1}$, DANELA MURARIU ${ }^{2 *}$
}

*E-mail: dmurariu@suceava.astral.ro

Received: Oct. 29, 2019. Revised: Nov. 18, 2019. Accepted: Nov. 27, 2019. Published online: Dec. 20, 2019

\begin{abstract}
Nitrogen is an important element required for plant growth and development. It is a key component in many biological compounds that play a major role in photosynthetic activity and crop yield capacity. Variation in nitrogen availability can affect plant development and productivity in maize. One of the ways of soil pollution through agricultural technology is over-fertilization and, in particular, the administration of high doses of nitrogen fertilizers. Excess of nitrogen fertilizers, as well as their empirical application, have negative effects on harvest quality. Excessive use of fertilizers with nitrogen, produces of ion nitric accumulation in the soil (temporary) and in plants, which disturbs the balance of photosynthesis, causes the appearance of necrosis and burns on leaves, severe intoxication and even death by asphyxiation phenomena and cyanosis at ruminants, children and old people. The main aim of this study was to determine the effect of different nitrogen levels and different type of fertilizers on nitrates levels in maize leaves and on
\end{abstract}

morphological traits of maize plants. Field experiments were conducted in two growing seasons (2017 and 2018) with five nitrogen levels $(80 \mathrm{~kg} / \mathrm{ha}, 120 \mathrm{~kg} / \mathrm{ha}$, $160 \mathrm{~kg} / \mathrm{ha}, 200 \mathrm{~kg} / \mathrm{ha}$ and $240 \mathrm{~kg} / \mathrm{ha}$ ) and two type of nitrogen fertilizers (ammonium nitrate and urea).

Keywords: ammonium nitrate; urea; maize; chemical fertilizers.

\section{INTRODUCTION}

In the last decade, yield grains have been increasing. In maize, it has been associated with the increase of the nitrogen use (Hirel et al., 2001), which the farmers still believe that the high level can guarantee a safety harvest (Montemurro et al., 2006), and the nutrient used above is the most important in the vegetable development (Presterl et al., 2002).

The nowadays, the levels of nitrogen fertilizer used in the corn crop can be involved with the aquifer

\footnotetext{
1 University of Agricultural Sciences and Veterinary Medicine Cluj-Napoca, Romania

2 Suceava Genebank, Romania
} 
contamination (Plăcintă, 2005) or any type of natural resource, decreasing its quality (Al-Kaisi and Yin, 2003). Also, some extra activities can help the nitrogen efficiency (Cui et al., 2009), such as using a narrow row spacing, decreasing the fertilizer through increasing of recovery efficiency (Barbieri et al., 2008), crop rotation and the use of organic fertilizer (Montemurro et al., 2006).

Many plant species (fodder plants, spinach, carrot, cabbage, etc.) have high capacity to accumulate nitric ion, which leads to diminished qualities of these products from the nutritional point of view, in the case of excessive nitrogen doses (Davidescu and Neaţă, 1992; Lăcătusu et al., 1992; Răuţă and Cârstea, 1983; Teşu and Baghinschi, 1984; Davidescu, 1980; Davidescu et al., 1992; Dumitru et al., 1994; Bibicu, 1997). Therefore, it is necessary to establish and quantify the impact of nitrates on soil, the environment and plants.

\section{MATERIAL AND METHODS}

For the study of nitrat contents in maize plants (trilinear hybrid Suceava M), it used a factorial combination of two factors: type of fertilizer and $\mathrm{N}$ rates. The experiments was placed at the Suceava Agricultural Research and Development Station, Romania, in two growing seasons (2017 and 2018), in randomized complete block design (RCBD) with randomly placed variants.

The two nitric fertilizers (ammonium nitrate and urea) were applied after the emergence of the plants, using the following variants:
$\mathrm{V}_{1}$ - unfertilized control; $\mathrm{V}_{2}-\mathrm{N}_{80}$; $\mathrm{V}_{3}-\mathrm{N}_{120} ; \mathrm{V}_{4}-\mathrm{N}_{160} ; \mathrm{V}_{5}-\mathrm{N}_{200} ; \mathrm{V}_{6}-\mathrm{N}_{240}$. The plot was maintained by manual work on rows and between rows. The plant samples were taken in three distinct periods: when the plants had five leaves, at flowering, and at maturing in milk. Also, the morphological descriptors to the plants, ears and kernels were made during vegetation period, after flowering.

Soil study site was a degraded chernozem with high clay content. A chemical analysis performed one month before installing the trial indicated the following soil characteristics: humus $3,86 \%$; clay - 27,96\%; P-Al - 53,2 ppm; $\mathrm{K}-\mathrm{Al}$ - 117 ppm; pH (water) - 4,88; Nt (s.u.) - 0,186\%; $\mathrm{Al}-0,35 \mathrm{me} / 100 \mathrm{~g}$.

Chemical analyses in plants and soil were performed by chemical and physicochemical methods (Schollemberger method; Kacinscki method; colorimetric method).

\section{RESULTS AND DISCUSSION}

The impact of the two fertilizers (ammonium nitrate and urea), through nitrates content, on different morphological descriptors is presented in Table 1.

From the presented data (Table 1) it is note very significant correlations between nitrates content and some morphological data (ear height, minimum diameter of ear), when was applied ammonium nitrate. Also, there are the same significant correlations when it used urea fertilizer, but for other morphological descriptors (plant height, maximum diameter of the stem, minimum diameter of the stem, minimum diameter of ear, weight of ear/plant). For emphasize of this, we 
have drawn regression lines between nitrates content and some important morphological traits.

In Figs. 1 and 2 it is noticed very significant negative correlations between the nitrates content and the minimum diameter of the ear and significant negative correlations between the nitrates content and number of kernels/row when it apply the both fertilizers. Referring the weight ear / plant it is noticed significant positive correlations between nitrates content and weight of ear/plant when it apply ammonium nitrate and very significant negative correlations when it apply urea fertilizer (Figs. 3 and 4).

Table 1 - Correlation coefficients between nitrate content and morphological descriptors of the trilinear Hybrid Suceava M

\begin{tabular}{|c|c|c|c|c|c|}
\hline \multicolumn{3}{|c|}{ Ammonium nitrate fertilizer } & \multicolumn{3}{|c|}{ Urea fertilizer } \\
\hline $\begin{array}{l}\text { Morphological } \\
\text { traits }\end{array}$ & $\begin{array}{l}\text { Nitrates } \\
\text { contents }\end{array}$ & $\begin{array}{l}\text { Signifi- } \\
\text { cance }\end{array}$ & $\begin{array}{l}\text { Morphological } \\
\text { traits }\end{array}$ & $\begin{array}{l}\text { Nitrates } \\
\text { contents }\end{array}$ & $\begin{array}{l}\text { Signifi- } \\
\text { cance }\end{array}$ \\
\hline Plant height $(\mathrm{cm})$ & 0.344 & - & Plant height (cm) & 0,844 & $* \star \star *$ \\
\hline Ear height $(\mathrm{cm})$ & 0,660 & *** & Ear height $(\mathrm{cm})$ & -0.195 & - \\
\hline $\begin{array}{l}\text { Maximum diameter } \\
\text { of stem }(\mathrm{mm})\end{array}$ & 0.395 & - & $\begin{array}{l}\text { Maximum diameter } \\
\text { of stem }(\mathrm{mm})\end{array}$ & 0.800 & $* * *$ \\
\hline $\begin{array}{l}\text { Minimum diameter } \\
\text { of stem }(\mathrm{mm})\end{array}$ & -0.768 & 000 & $\begin{array}{l}\text { Minimum diameter } \\
\text { of stem }(\mathrm{mm})\end{array}$ & -0.715 & 000 \\
\hline $\begin{array}{l}\text { Total numbers of } \\
\text { leaves }\end{array}$ & -0.01 & - & $\begin{array}{l}\text { Total numbers of } \\
\text { leaves }\end{array}$ & -0.01 & - \\
\hline Leaf length $(\mathrm{cm})$ & 0.155 & - & Leaf length $(\mathrm{cm})$ & 0.140 & - \\
\hline Leaf width $(\mathrm{cm})$ & -0.195 & - & Leaf width $(\mathrm{cm})$ & -0.195 & - \\
\hline Ear length $(\mathrm{cm})$ & -0.510 & 0 & Ear length $(\mathrm{cm})$ & $-0,105$ & - \\
\hline $\begin{array}{l}\text { Maximum diameter } \\
\text { of ear }(\mathrm{mm})\end{array}$ & -0.329 & - & $\begin{array}{l}\text { Maximum diameter } \\
\text { of ear }(\mathrm{mm})\end{array}$ & $-0,384$ & - \\
\hline $\begin{array}{l}\text { Minimum diameter } \\
\text { of ear }(\mathrm{mm})\end{array}$ & -0.923 & 000 & $\begin{array}{l}\text { Minimum diameter } \\
\text { of ear }(\mathrm{mm})\end{array}$ & $-0,826$ & 000 \\
\hline $\begin{array}{l}\text { Number of } \\
\text { kernels/row }\end{array}$ & -0.574 & 00 & $\begin{array}{l}\text { Number of } \\
\text { kernels/row }\end{array}$ & $-0,503$ & 0 \\
\hline Kernel length (mm) & 0.290 & & Kernel length (mm) & 0,537 & ** \\
\hline Kernel width (mm) & -0.231 & & Kernel width (mm) & 0,572 & ** \\
\hline $\begin{array}{l}\text { Kernel thickness } \\
(\mathrm{mm})\end{array}$ & -0.397 & & $\begin{array}{l}\text { Kernel thickness } \\
(\mathrm{mm})\end{array}$ & $-0,059$ & - \\
\hline $\begin{array}{l}\text { Weight of grains/ear } \\
\text { (g) }\end{array}$ & 0.021 & & $\begin{array}{l}\text { Weight of grains/ear } \\
\text { (g) }\end{array}$ & $-0,352$ & - \\
\hline $\begin{array}{l}\text { Weight of ear/plant } \\
\text { (g) }\end{array}$ & 0.590 & ** & $\begin{array}{l}\text { Weight of ear/plant } \\
\text { (g) }\end{array}$ & $-0,982$ & 000 \\
\hline $\begin{array}{l}\text { Moisture content of } \\
\text { kernels (\%) }\end{array}$ & -0.229 & - & $\begin{array}{l}\text { Moisture content of } \\
\text { kernels (\%) }\end{array}$ & 0,071 & - \\
\hline $\begin{array}{l}\text { Weight of sample } \\
\text { (five ears) (g) }\end{array}$ & -0.509 & 0 & $\begin{array}{l}\text { Weight of sample } \\
\text { (five ears) (g) }\end{array}$ & 0,530 & ** \\
\hline Sample yield (\%) & 0.516 & 0 & Sample yield (\%) & 0,040 & - \\
\hline
\end{tabular}




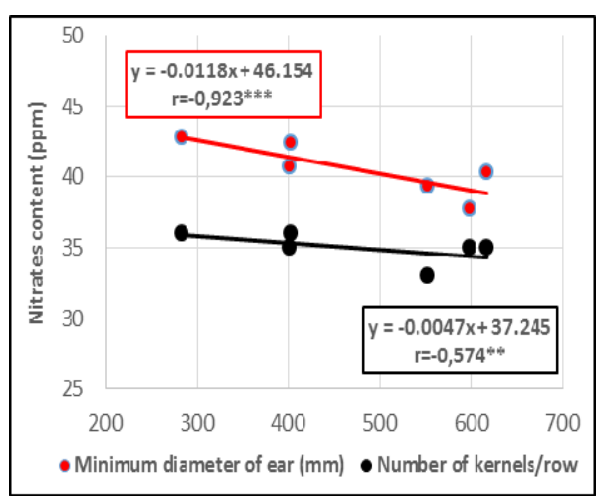

Figure 1 - Regression lines for the correlation between the nitrates content and morphological traits (minimum diameter of ear and number of kernels/row) when it used ammonium nitrate

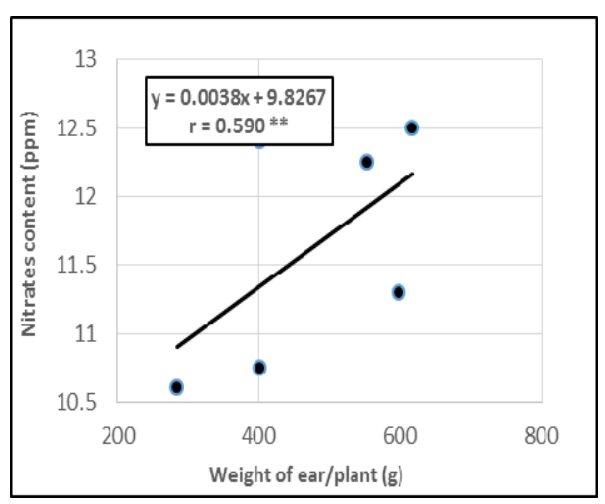

Figure 3 - Regression line for the correlation between the nitrates content and weight of ear/plant when it used ammonium nitrate

Referring to nitrates content on maize leaves, the big values of this chemical compound are observed at high quantities of fertilizers with nitrogen. The biggest values are registered in the first stage. Also, is notice a big difference between that two types of fertilizers. In case of

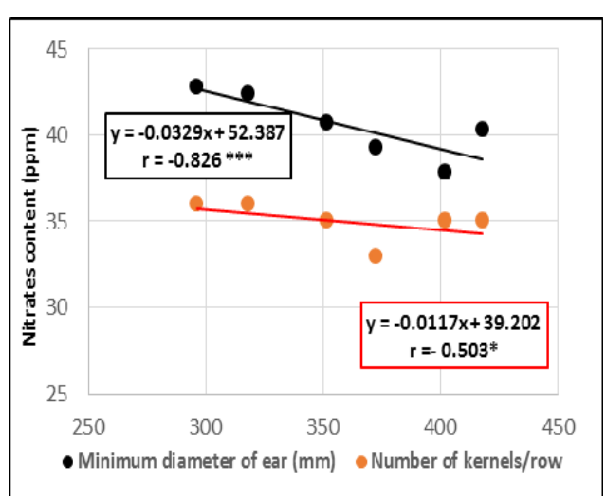

Figure 2 - Regression lines for the correlation between the nitrates content and morphological traits (minimum diameter of ear and number of kernels/row) when it used urea fertilizer

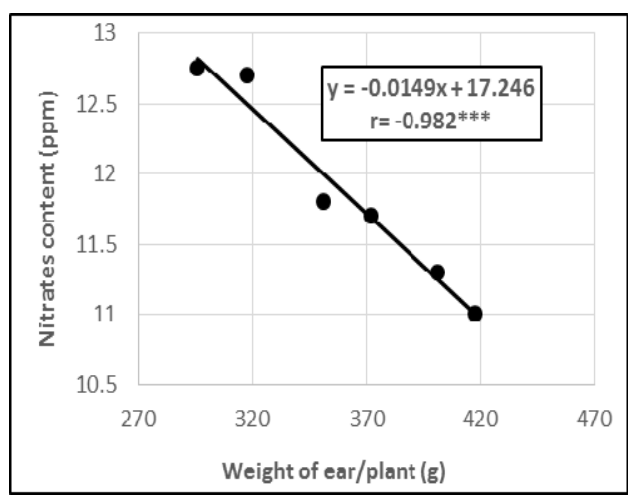

Figure 4 - Regression line for the correlation between the nitrates content and weight of ear/plant when it used urea fertilizer

urea, the level of nitrates is smaller than in ammonium nitrate. In Fig. 5 is observed that the nitrates content is highest in first development stage when it is used ammonium nitrate. 


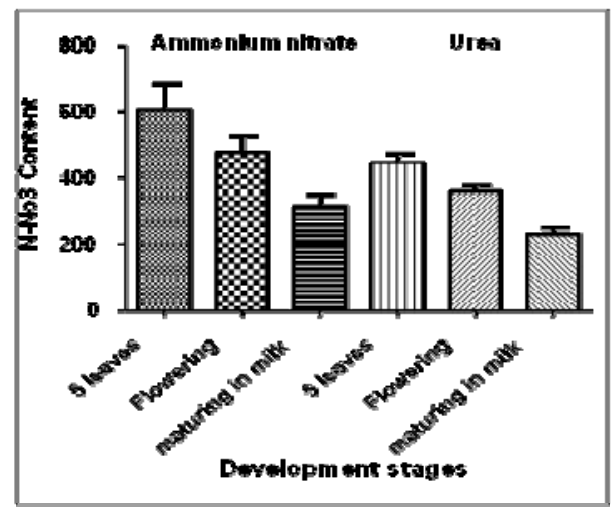

Figure 5 - The nitrate content in three development stages of plants depending on the fertilizer used

\section{CONCLUSIONS}

It was concluded from this study, the type of fertilizer have a big influence on morphological descriptors.

Regarding the presence of relationship between nitrates content from plants and different morphological descriptors, significant correlations were observed between nitrates content and some morphological descriptors at both type of fertilizers.

Referring to presence of nitrates in plants it was concluded that the level of nitrates is biggest when plants have five leaves and it is apply the ammonium nitrate fertilizer.

\section{REFERENCES}

Al-Kaisi, M.M. \& Yin, X. (2003). Effects of nitrogen rate, irrigation rate, and plant population on corn yield and water use efficiency. Agron.J., 95(6):
1475-1482; DOI:10.2134/agronj2003 .1475

Bibicu, Miruna (1997) Poluarea cu nitrati, un factor restrictiv în vânzarea legumelor de seră (Nitrate pollution, a restrictive factor in the sale of greenhouse vegetables). Hortinform, Vol. IV, No.1, Bucharest.

Cui, Z., Zhang, F., Mi, G., Chen, F., Li, F., Chen, X., Li, J. \& Shi, L. (2009). Interaction between genotypic difference and nitrogen management strategy in determining nitrogen use efficiency of summer maize. Plant Soil, 317(1-2): 267-276; DOI: 10.1007/s11104-008-9807-x

Davidescu, D. (1980). Aspecte ecologice ale chimizării agriculturii (Ecological aspects of agricultural chemization). Analele celui de-al II-lea Simp.Naț.Prot.Ecosist., Pitești.

Davidescu, Velicica \& Neață, Gabriela (1992). Poluarea mediului. SurseCombatere. (Environmental pollution. Sources-Control). AMD-IANB, București.

Dumitru, M., Răuță, C., Toti, M. \& Gamet, Eugenia (1994). Evaluarea gradului de poluare a solului. Măsuri de limitare a efectului poluant (Evaluation of degree of soil pollution. Measures to limit the 


\section{INFLUENCE OF NITRATE CONTENTS ON MAIN MORPHOLOGICAL TRAITS OF MAIZE PLANTS}

pollutant effect). Lucr.Conf.Naț.Șt. Sol., Tulcea, Romania.

Hirel, B., Le Gouis, J., Ney, B. \& Gallais, A. (2007). The challenge of improving nitrogen use efficiency in crop plants: towards a more central role for genetic variability and quantitative genetics within integrated approaches. J.Exp.Bot., 58(9): 2369-2387, DOI: 10.1093/jxb/ erm097

Lăcătușu, R., Răuță, C., Toti, M. \& Gamet, Eugenia (1994). Poluarea solului cu emisii industriale și prin aplicarea tehnologiilor agricole intensive (Soil pollution with industrial emissions and by the application of intensive agricultural technologies). Rev. Agric., București.

Montemurro, F., Maiorana, M., Ferri, D. \& Convertini, G. (2006). Nitrogen indicators, uptake and utilization efficiency in a maize and barley rotation cropped at different levels and sources of $\mathrm{N}$ fertilization. Field Crop Res., 99(2-3): 114-124, DOI: 10.1016/j.fcr.2006.04.001
Plăcintă, Domnica-Daniela (2005). Contribution to the study of the action of parasite and saprophyte flora on the viability of bean seeds, International Symposium "Agriculture and Environment, Presents and Perspectives". Annals of Agricultural University and Medicine Veterinary University., Vol. 48.

Presterl, T., Groh S., Landbeck, M., Seitz, G., Schmidt, W. \& Geiger, H.H. (2002). Nitrogen uptake and utilization efficiency of European maize hybrids developed under conditions of low and high nitrogen input. Plant Breed., 121: 480-486, DOI: $10.1046 / \mathrm{j} .1439-0523.2002 .007$ 70.x

Răuță, C. \& Cârstea, Șt. (1983). Prevenirea și combaterea poluării solului (Prevention and control of soil pollution). Edit. Ceres, București.

Teșu, I. \& Boghinchi, V. (1984). Énergia și agricultura (Energy and agriculture). Edit. Ceres, București. 